\title{
Fé cristã plural: a chance do retorno à catolicidade
}

\author{
Plural christian faith: \\ the chance of a return to Catholicism
}

Volney J. Berkenbrock

\section{Resumo}

O pluralismo cultural é um fenômeno cada vez mais presente em nossa sociedade, chamado muitas vezes de pós-modernidade. Quais consequências esta situação traz para a fé cristã? Esta pergunta pode ser respondida de diversas maneiras. Há a possibilidade de se pensar o pluralismo como desafio ao cristianismo. Há a possibilidade de se pensar quais desafios traz esta situação para a igreja e sua organização pastoral. Este presente texto pretende ver este fenômeno sob outro ponto de vista, ou seja, o pluralismo cultural como uma chance de a fé cristã retornar a uma de suas características primitivas: a da catolicidade. O pluralismo esteve e está presente de forma positiva na dinâmica da fé cristã ao longo da história e o pluralismo cultural representado pela pós-modernidade apresenta a possibilidade de o cristianismo encarnar-se concretamente neste tempo histórico. Dado que o cristianismo já fez isto historicamente muitas vezes, esta nova situação não deve ser vista como adversa, mas sim positivamente como chance. $\mathrm{O}$ texto irá apontar algumas destas chances para o cristianismo.

Palavras-chave: Pluralismo, pós-modernidade, catolicidade.

\section{Abstract}

Cultural pluralism is a phenomenon increasingly present in our society, often called postmodernity. Which consequences does this situation bring to 
the Christian faith? This question can be answered in several ways. Pluralism could be understood as a challenge to Christianisme. There is the possibility of thinking which challenges this situation brings to the church and to its pastoral organization. This study intends to see at this phenomenon from another point of view, in other words, cultural pluralism as a chance of Christian faith to return to one of characteristics of its primitive features: the catholicity. Pluralism has been and is still positively present on the dynamics of Christian faith along history and cultural pluralism represented by postmodernity offers the possibility of Christianity to incarnate concretely in this particular historical time. Given that Christianity has historically done this many times, this new situation should not be seen as adverse, but positively as a chance. The text will indicate some of these chances to Christianity.

Keywords: Pluralism, postmodernity, catholicity.

\section{Introdução}

O tema do pluralismo tem sido bastante caro a muitas reflexões nos dias atuais, como um dos conceitos capazes de descrever diversos fenômenos que se observam na sociedade atual. O conceito pode ser usado na área de mercado, da política, da sociologia, do ensino, etc., para apontar uma das características de nossas sociedades neste tempo chamado por alguns de pós-modernidade, por outros de modernidade tardia, por outros de hipermodernidade ou então também de sobremodernidade.

Uma das áreas onde o pluralismo também tem sido percebido e discutido é o da teologia cristã e como este fenômeno incide tanto sobre o pensar teológico, como sobre a vivência comunitária da fé (a eclesialidade) ou a vivência individualizada da fé (a religiosidade). É neste contexto que se insere a reflexão nestas linhas.

Mas mesmo contextualizando a reflexão do pluralismo dentro da teologia, queria deixar claro deste o inicio o que não será abordado nesta reflexão. Não é nosso intento aqui abordar o fenômeno da pluralidade religiosa e suas consequências para o cristianismo ou para o catolicismo. É óbvio que este é um tema importante e já foi tratado por muitos autores. Também não é intento nosso abordar a realidade do pluralismo religioso como desafio para o cristianismo, por mais desafiador que ele seja. Igualmente não será objeto de reflexão a questão de se pensar como a Igreja pode agir e reagir à pluralidade 
religiosa, ou seja, não será aqui objeto de reflexão pensar propostas pastorais que respondam adequadamente a este fenômeno.

Este texto tem tão somente a singela intenção de pensar sobre a possibilidade de se ver elementos positivos para a fé cristã neste contexto plural. Se o pluralismo pode representar um desafio para o cristianismo, pode exigir que ele se adapte a estes novos tempos, pode questionar diversos aspectos da tradição, ele pode - e isto vou tentar mostrar - por outro lado representar uma chance à tradição de fé cristã de retornar a um elemento básico de sua tradição: a catolicidade, isto é, a capacidade de ser mais abrangente, mais inclusiva, mais aberta a possibilidades múltiplas aceitas e acolhidas como positivas e legítimas dentro de sua tradição.

\section{Pluralismo}

Antes de iniciarmos a proposta de reflexão, será necessário esclarecer o que estamos entendendo por pluralismo. É um tema amplo e por isso faço aqui apenas algumas delimitações e apontamentos, se qualquer pretensão de exclusividade ou exaustão.

\section{a) Pluralismo: deslocamento cultural}

Em nossa sociedade brasileira, a pluralidade é cada vez mais uma realidade. Pluralidade deve ser entendida como a realidade da diversidade. Há cada ver mais diversidade em todos os níveis. A realidade da pluralidade está levando ao pluralismo. Este entendo não mais apenas como a realidade da pluralidade, mas como uma nova forma cultural. Trata-se, pois de uma passagem do fenômeno da pluralidade para uma forma ou maneira de ler, entender, interpretar e viver nesta nova realidade.

Há aqui, pois, o que chamaria de deslocamento cultural. Estamos adentrando numa situação onde a pluralidade como fenômeno gerou ou está gerando uma cultura plural. Neste sentido, o pluralismo é o termo que estou aqui utilizando para diferenciar o fenômeno (a pluralidade), de sua influência na nossa sociedade ocidental (o pluralismo). Como processo de deslocamento cultural, o pluralismo é algo amplo em termos de abrangência, de tempo e de incidência. Ou seja, não podemos dizer isto já seja uma realidade em todos os lugares nem em todos os segmentos da sociedade, que é um processo longo (que vem já de muitas décadas) e não necessariamente atinge todas as camadas da sociedade da mesma maneira, sendo pois de incidência diversa. 
Mas por outro lado não se pode negar que o pluralismo seja um processo em andamento e que está influenciando setores de nossa sociedade. Como se trata de um processo em andamento, se pode perguntar: Para onde vai? Isto claramente não sabemos. Esta questão é abordada pelos futurologistas. Sim, há os futurologistas, profissão não muito conhecida entre nós no Brasil, mas mais nos EUA e que nada tem a ver com cartomancia ou adivinhação. Os futurologistas estão muito mais ligados à economia e para não dizer que fazem previsões, o que eles tentam é detectar são as chamadas tendências: tendências do mercado, tendências políticas, tendências econômicas, tendências comportamentais, etc ${ }^{1}$.

Não é o nosso caso. O que podemos dizer não é apenas que vivemos em um tempo de mudanças: sim, sempre vivemos em um tempo de mudanças. A história sempre foi dinâmica e composta simultaneamente por muitos dinamismos. A questão é tentar entender quais as mudanças de agora, as mudanças em curso. Sempre é mais fácil perceber as mudanças ocorridas quando já se passou algum tempo, com um olhar distanciado. Mas tentar observar as mudanças enquanto ocorrem, é algo mais difícil. O pluralismo como uma nova forma cultural é, no meu entender, uma destas mudanças que ocorre em nosso meio e nos encontramos no meio dela.

\section{b) Pluralismo como forma de ver o mundo}

Há dois elementos que queria destacar no que chamo de pluralismo. Estão interligados, mas gostaria de dividi-los didaticamente. Uma coisa é o pluralismo como forma de ver o mundo, ou seja, um modo de pensar e interpretar a realidade. Poderíamos talvez dizer que sempre houve pluralidade, mas não a víamos assim. Não seria o pluralismo uma mudança que se deu mais no nosso modo de pensar, interpretar e ler o mundo do que de organizar o mundo?

Penso que a maior mudança trazida pelo pluralismo não é a da realidade da pluralidade. De formas diversas, esta sempre esteve presente. A maior mudança talvez esteja no fato de que agora estamos percebendo isto: ou seja, o ser humano está tendo a sensibilidade necessária para esta realidade. $\mathrm{O}$ pluralismo seria, pois mais uma ferramenta de visão, um óculos hermenêutico, do que necessariamente mudanças externas, mudanças estas geralmente

\footnotetext{
${ }^{1}$ Exemplo disto pode ser visto na obra Além da Crise - O futuro do capitalismo, onde o autor é apresentado da seguinte maneira: "O futurologista ADJIEDJ BAKAS pesquisa tendências econômicas, tecnológicas, culturais e espirituais ao redor do mundo" (orelha do livro). BAKAS, A. Além da Crise - O futuro do capitalismo. Rio de Janeiro: Qualitymark, 2010.
} 
apontadas como comprovação da existência do pluralismo. Teríamos mais mudando a forma de ver, que as coisas vistas? Este é o primeiro elemento a ser chamado atenção quando falamos de pluralismo: trata-se de uma forma de ver ou entender a nossa volta.

\section{c) Pluralismo como forma de vida}

Outra coisa é o pluralismo como forma de vida. Vivemos já em parte de tal maneira que o pluralismo tornou-se mais que uma forma de interpretar o mundo, tornou-se uma forma na qual nós vivemos e (talvez) nem percebemos. Exemplificando, tendo a religião como ponto de partida: por um lado começa a fazer parte de nosso pensar a compreensão de que é legítimo que cada pessoa escolha a sua religião (pluralismo como forma de ver o mundo), por outro lado, se analisamos à nossa volta (nossa família, nossa vizinhança, os colegas de trabalho) veremos que há já um pluralismo religioso instalado e do qual simplesmente tomamos conhecimento. Vivemos dentro dele e ele, neste sentido não é apenas uma forma de ver o mundo, mas uma forma de viver. Poderíamos tomar outros exemplos como o casamento, a sexualidade, etc.

Nestes exemplos podemos ver o pluralismo pois como uma forma de vida existente em nossa sociedade. É o que chamaria de pluralismo cultural: mais do que uma forma de interpretação, é uma forma de vida, talvez nem tanto refletida, mas instaurada lentamente, como se instauram a maioria das mudanças culturais.

\section{d) O que é o pluralismo?}

Claro que é muito difícil dizer o que é pluralismo em uma definição. Já fizemos acima uma diferenciação entre pluralidade e pluralismo. Para nos achegarmos mais ao conceito de pluralismo, vamos tentar demonstrar algumas características pelas quais o pluralismo cultural se expressa.

Um primeiro elemento do pluralismo cultural é a proximidade da convivência com a diversidade. Nas situações de pluralismo, a diversidade não apenas é uma realidade, mas uma realidade em convivência. A diversidade habita os mesmos espaços e neles convive. Assim, em termos de religião, a diversidade religiosa convive não apenas no espaço mais amplo que denominamos sociedade, mas também em espaços mais próximos que são as comunidades, os bairros, a vizinhança. Mais que isto, a diversidade religiosa convive 
em espaços ainda mais próximos que o local de trabalho, o local de lazer e inclusive as mesmas famílias. Proximidade de convivência não necessariamente significa convivência harmoniosa ou pacífica. Podem também existir conflitos e tensões. Mas, mesmo com estes, a proximidade de convivência cria a aceitação da diversidade como legítima.

Um segundo elemento a se chamar atenção como característica do pluralismo é a situação de oferta de possibilidades. Há muitas possibilidades sendo ofertadas, nada (ou quase nada) mais é singular. O mercado, os serviços, o comércio são talvez os lugares mais claros desta situação de oferta de possibilidades. Mas esta oferta de possibilidades também se manifesta em ofertas muitas de sentido, em ofertas muitas de compreensão do mundo, de escolha de forma de vida, de profissões a serem escolhidas, de escolhas políticas (ou contra elas!), e, o que a nós aqui especialmente interessa, a situação de oferta de possibilidades de opções religiosas, de opções espirituais ou de filosofia de vida.

Outra característica do pluralismo a chamar a atenção aqui é que a situação de oferta de possibilidades leva a alguns deslocamentos, típicos de uma situação de pluralismo. Um primeiro deslocamento é a necessidade da escolha. Como não há mais ofertas únicas, as coisas precisam ser escolhidas. Nesta situação, a opção desloca-se do certo X errado, para a situação de escolhido X rejeitado. A situação de muitas possibilidades a serem escolhidas, faz com que surja a igualdade de princípio entre as possibilidades (em princípio, todas as opções estão em pé de igualdade); sendo elas em princípio iguais, há também a legitimidade de princípio entre as opções (em princípio, todas as opções são percebidas como legítimas). A consequência disto é que não há - em princípio - uma hierarquia de valores entre as opções disponíveis. A hierarquia de valores é constituída a partir das escolhas. As escolhas fazem com que algo seja posto em primeiro ou em último lugar na hierarquia de valores. Não há, assim, valores em si, há valores sempre atribuídos.

Mais um elemento a ser aqui observado é que o pluralismo leva ao fim dos macrossistemas de sentido ou pelo menos à diminuição de sua importância. Há muitas opções de sentido sendo ofertadas e que - por sua vez - são objeto de escolha. Diante disto há um sentimento de fragmentação: muitas ofertas de sentido concorrem em pé de igualdade. Não se trata pois de falta de sentido; pelo contrário, há uma inflação de sentidos sendo ofertados como possibilidades. O que faz um sentido ser verdadeiro é o fato de ele ser escolhido. Verdadeiras são não as opções disponíveis, verdadeiras são as opções escolhidas. 
Um último elemento que queria chamar atenção aqui na situação de pluralismo cultural é a sacralidade da individualidade. Como boa parte do sistema está baseado na escolha do indivíduo, este passa a ter um papel central no pluralismo cultural. Com a igualdade de princípio do que pode ser escolhido e a legitimidade de princípio do que pode ser escolhido, o poder (a importância) de um sentido deixa de ser algo em si. Este passa para aquele que escolhe: o indivíduo. Numa situação de cultural plural, a individualidade passa a ter ares de sacralidade. Z. Bauman, em sua obra O Mal-Estar da Pós-Modernidade vai dizer que nestes tempos tudo é líquido, tudo é móvel, tudo está à disposição, menos a importância da individualidade. Esta foi levada a um patamar que não está à disposição Esta precisa ser preservada a qualquer custo ${ }^{2}$.

\section{Pluralismo e fé}

Poderíamos nos alongar em tentar demonstrar o que é e como se manifesta o que estamos chamando de pluralismo cultural. Nosso intento, no entanto, é porém fazer uma relação deste com a fé. É a isto que vamos agora nos dedicar, também em alguns tópicos.

\section{a) Fé e pluralismo: uma falsa contraposição}

Quando se quer pensar a relação entre fé e pluralismo, é comum que se veja ali uma contradição: a ideia de que uma situação de pluralismo cultural pode representar um problema para a fé cristã, dado que esta seria mais ou menos monolítica, com uma compreensão única ou unificada, não disponível a muitas opções, etc. Mais que isto, é comum que se veja no pluralismo cultural um perigo para a identidade cristã, dado que ela poderia - neste mundo cheio de muitos sentidos a serem escolhidos - perder a sua identidade. Vê-se, pois, o pluralismo cultural sobretudo como um perigo para a identidade cristã. Este precisaria ser reforçada para não sucumbir. Esta posição é, porém apenas uma maneira de ver a situação da fé cristã num contexto de pluralismo cultural. É possível pensar esta relação de maneira positiva.

Ao dizer que esta é apenas uma maneira de ver esta relação e que é possível pensar esta relação de forma positiva, não se está negando que este modo de pensar e viver que estamos chamando de pluralismo cultural não

\footnotetext{
${ }^{2}$ Cf. BAUMAN, Z., O Mal-Estar da Pós-Modernidade. Rio de Janeiro: Zahar, 1998, p. 30.
} 
impacte a fé cristã. É óbvio que há aqui uma situação impactante para a fé. Mas pensar impacto é algo diferente de pensar contradição.

Vejamos como se pode ver esta relação de forma diferente. Pensar que a realidade fé e a realidade pluralismo sejam contrapostas, é um falso pressuposto. O pluralismo é uma realidade cultural que está se instalando, uma forma de pensar, de ler de interpretar e de viver o mundo. A fé sempre acontece dentro de um contexto cultural. Ela não é algo paralelo à cultura. Como afirmava Tillich em sua conferência poucos dias antes de falecer, "a história das religiões, em sua natureza essencial, não existe ao lado da história da cultura. O sagrado não está ao lado do secular, mas ele é a sua profundidade"3. Pensar fé como algo contraposto a cultura seria pensar em pessoas de fé que estariam vivendo à margem da sociedade, ou em uma sociedade paralela. $\mathrm{Ou}$ pior que isto, seriam pessoas vivendo em uma espécie de divisão esquizofrênica: por um lado vivem, convivem, atuam em uma sociedade pluralista, com muitos sistemas de sentido e por outro estariam numa outra condição no que se refere à fé: num mundo único, singular, monolítico.

Se há alguma contraposição, esta se dá ligada à questão de mudanças culturais. Estas sim criam contraposições ou - para usar a linguagem de Bauman - mal-estar. O que não é necessariamente algo explícito do ponto de vista do discurso, mas muito mais algo que brota do sentimento, por isso mal-estar. As mudanças geral mal-estar, pois necessitam de adequações. Neste sentido, vejo que o fenômeno do pluralismo cultural cria um mal-estar para o crente, mas isto por necessidade de adaptação.

Processos de mudança cultural não ocorrem sem tensões. E o fato de os cristãos estarem envolvidos nestas tensões mostra justamente que eles estão vivendo este processo e não que este seja contraposto à fé cristã.

\section{b) Fé numa situação de pluralismo}

Se a contraposição entre fé e situação de pluralismo é uma falsa contraposição, devemos falar então não em uma fé contra o pluralismo ou em um pluralismo como adversário à fé. Devemos falar de fé numa situação de pluralismo. A situação cultural onde a fé é vivida é a de pluralismo. Pluralismo cultural e fé não são, pois dois mundos separados ou paralelos ou contrapostos. O fiel cristão está dentro de um mundo plural e é ali que ele vive a sua

\footnotetext{
${ }^{3}$ P. Tillich aqui resumido por: RIBEIRO, C. de O. "Ecumenismo, pluralismo e religiões. A
} busca de novos referenciais". REB 287 (2012), p. 656. 
fé. Como a situação de pluralismo cultural é ainda uma realidade que está se manifestando, que está em ascendência, toda a sociedade encontra-se neste processo, com as tensões nele inerentes. A tensão vivida pelo fiel cristão é, em termos, a mesma vivida por outras pessoas nesta sociedade em mudança. As dificuldades para se viver a fé nesta nova situação não têm origem na contradição entre fé e esta nova situação cultural, mas sim nas tensões próprias de todas as mudanças culturais, onde há camadas da população que pensam, agem, interpretam o mundo de uma forma e outras camadas que pensam, agem e interpretam o mundo de outra forma. Estas diferenças são fonte de tensão.

Isto, para a história da vivência da fé cristã não é, porém, nenhuma novidade. Como existiu a fé cristã no contexto cultural do império romano, a fé cristã no período medieval, no período da modernidade, etc. E não podemos imaginar que estas mudanças culturais não tenham trazido tensões para a fé cristã. Muitas são as informações que temos destes períodos de tensões. Quando o cristianismo primitivo sai do mundo judaico para entrar no mundo grego, esta passagem é fonte de tensões. $\mathrm{O}$ apóstolo Paulo já enfrentou tais tensões e deixou isto claro em suas cartas. Por um lado tensões advindas da necessidade de sair da cultura judaica, da qual o cristianismo era oriundo: basta ver as controvérsias em torno da necessidade ou não da circuncisão dos gentios. Por outro lado, a tensão com o modo de pensar grego, para o qual o anúncio do apóstolo soava como escândalo. $\mathrm{O}$ advento da cultura medieval foi outra fonte de tensões, da qual os cristãos participaram ativamente. Como adaptar-se à nova estruturação social de senhores e vassalos, de relação entre poder mundano e religioso? Os cristãos novamente viram-se envolvidos por estas tensões, justamente por estarem vivendo sua fé neste período de transição. A longa passagem do mundo cultural medievo para o iluminismo e a chamada sociedade moderna gerou tensões múltiplas: econômicas, políticas, sociais, etc. E ali novamente os fieis cristãos participaram das mesmas. Basta pensar na teologia neo-escolástica e sua tentativa de refutação do iluminismo ou na encíclica Quanta Cura do Papa Pio IX, com os Syllabus contendo uma lista dos 80 "principais erros do nosso tempo". Nenhuma destas grandes mudanças culturais ocorreu sem tensões e em todas estas mudanças das quais participaram, os fieis cristãos ficaram ilesos do processo de tensão.

Numa compreensão de história de longos períodos, as tensões atuais na passagem cultural que começa a se manifestar de modernidade para a pós-modernidade (ou outro nome pelo qual se queira chamar este período) não representam novidade absoluta. Mostram apenas a dinamicidade dos 
processos históricos. Para a nossa questão - a da fé cristão numa situação de cultura plural - nesta situação que está surgindo, o sujeito que tem fé é de uma cultura plural. Ou seja, ele sente, interpreta, vive a sua fé a partir desta sua situação, condição cultural. Como há nesta sociedade muitas pessoas que não estão dentro do processo da pós-modernidade, esta passagem é fonte de tensões em muitos níveis, também no da fé.

\section{c) Fé cristã plural: condição de crer e não só contexto de crença}

Com o avançar de uma situação de sociedade de pluralismo cultural, penso que devemos falar em fé cristã plural como uma condição de crer não apenas um contexto de crença, ou um contexto cultural no qual cristãos estão vivendo. Explicando: não se trata apenas de pensar que o fiel está num contexto de pluralismo e por isso agora pensa, interpreta e vive sua fé neste contexto. O sujeito que tem fé (o fiel) nesta cultura de pluralismo pensa, interpreta e vive a sua fé a partir deste modo pluralista de ser. Ou seja, o pluralismo não é apenas o seu contexto, é o seu ponto de partida.

Como o pluralismo como condição cultural é um processo em curso, as novas gerações, já nascidas dentro da condição de pluralismo cultural, irão pensar, viver e sentir a fé a partir desta sua condição cultural. A partir destas gerações teremos certamente uma outra condição de fé cristã na sua relação com o pluralismo cultural. As gerações que estão vivendo esta mudança, que nasceram, cresceram, aprenderam a interpretar e viver mundo de uma maneira não pós-moderna, irão sentir a maneira da pós-modernidade como uma nova situação (com todas as suas tensões e não só no que diz respeito à fé). Já as gerações nascidas numa situação de pluralismo cultural não apenas não sentirão esta tensão, mas - e isto considero importante - irão pensar, interpretar, viver a fé cristã tendo este pluralismo como ponto de partida cultural. Ele não será mais contraditório, ele será o lugar de onde se pensa, se interpreta, se vive a fé cristã.

Teremos assim, certamente, um cristianismo culturalmente diverso do daquele vivido em outros tempos históricos. Mas não consigo imaginar que esta mudança cultural irá colocar em risco a identidade cristã. Ou perguntando claramente: Esta nova condição cultural irá mudar o que se entende por fé cristã ou dito mais diretamente ainda, irá afetar a identidade da fé cristã? Com certeza, mas isto não é nenhuma novidade dentro da tradição cristã. Pelo contrário, o cristianismo não só está apto para estas mudanças, mas mais que isto: sua 
história mostra que a permanência da identidade cristã deveu-se em grande parte à sua capacidade de assumir as mudanças culturais como novos pontos de partida para a compreensão de sua fé. Diria mais que isto, o cristianismo sobreviveu historicamente não apesar das mudanças culturais e de sua capacidade de adaptação, mas há que se buscar em sua raiz teológica esta característica. Numa expressão: o efeito encarnação. A isto nos dedicaremos agora.

\section{Fé Cristã e construção de consensos}

Esta nova condição da fé (a fé dentro de uma cultura pluralista) não representa - a meu modo de ver - uma novidade absoluta para a tradição de fé cristã. Pelo contrário, ela está dentro do mais genuíno processo de concreção da fé cristã na história. Historicamente a fé cristã (os fieis cristãos) não apenas participou das mudanças culturais e suas tensões. Ela se constituiu nestes processos de mudanças culturais, sendo o processo de mudança não uma ameaça à identidade cristã, mas constitutivo de sua concreção histórica.

Vejamos alguns elementos:

\section{a) A compreensão de fé cristã não nasce pronta: é um processo}

O cristianismo nasce historicamente do evento páscoa. A experiência do ressuscitado - por mais controversa que possa ser a sua interpretação - é o fato desencadeador da comunidade cristã no sentido eclesial. A experiência do ressuscitado cria uma nova identidade ao grupo daqueles que seguiam Jesus, com ele viviam e acreditavam em sua proposta. A morte de cruz encerra este período dos seguidores de um pregador ambulante. A experiência da ressurreição refunda este grupo com uma nova identidade. Esta parece ser a inclusive a primeira auto-identidade cristã. Antes de se entenderem como cristãos, se entendem como "testemunhas da ressurreição". Isto aparece claramente duas vezes no início do texto dos Atos dos Apóstolos. A primeira passagem é a do contexto da escolha do sucessor de Judas, onde aparece no discurso de Pedro: "Convém, pois, que destes homens que têm estado em nossa companhia todo o tempo em que o Senhor Jesus viveu conosco, a começar do batismo de João até o dia em que foi elevado ao alto, um deles seja testemunha conosco de sua ressurreição" (At 1,21-22). E adiante, no discurso de Pedro em Pentecostes: "A este Jesus Deus ressuscitou e disso todos nós somos testemunhas" (At 2,32). Parece-me, pois evidente que esta é a primeira forma como este grupo 
de homens e mulheres de fé se auto-definem: testemunhas da ressurreição. Que tenham sido chamado de cristãos, isto aconteceu mais tarde. O próprio texto bíblico nos indica isto. O próprio Atos dos Apóstolos nos informa que "foi em Antioquia que, pela primeira vez, os discípulos foram chamados de "cristãos" (At 11, 26). Para Lucas, o fato de terem sido chamados de cristãos parece ter sido uma novidade interessante a ser recolhida em seu texto, com o acento preciso de "pela primeira vez". Sem discutir aqui a historicidade ou não da informação lucana, o texto conserva claramente a ideia de que a identidade deste grupo foi de "testemunhas da ressurreição" para "chamados de cristãos". Há aí, pois, já na comunidade primitiva um interessante deslocamento. E a segunda identidade (“cristãos”) nem foi, pelo que narra Lucas, auto-atribuída. Foi atribuída por outros e acolhida pelos "testemunhas da ressurreição".

Mas queria voltar à forma como a experiência do ressuscitado - da qual advém a primeira auto-identidade deste grupo - é narrada no texto bíblico. O texto bíblico acolhe narrativas múltiplas da experiência do ressuscitado. Há aqui um interessantíssimo fato de convívio de pluralidade: o próprio "ato fundante" da identidade da comunidade dos seguidores de Jesus (que mais tarde vão se chamar cristãos,) conhece narrativas múltiplas. Vejamos:

O Evangelho de Mateus fala de duas experiências do ressuscitado. Primeiro afirma que o ressuscitado apareceu às mulheres (Maria Madalena e a outra Maria). Depois das mulheres ouvirem o anjo dizer que Jesus não estava no túmulo, mas ressuscitara, as mulheres correram para dar a notícia aos discípulos. Mas “de repente, Jesus saiu ao encontro delas e disse-lhes: 'Salve!' Elas se aproximaram, abraçaram-lhe os pés e se prostraram diante dele. Disse-lhes então Jesus: 'Não tenhais medo! Ide dizer a meus irmãos que se dirijam à Galileia e lá me verão"” (Mt 28,9-10). A segunda aparição do ressuscitado foi na Galileia, "ao monte que Jesus lhes tinha indicado. Logo que o viram prostraram-se; alguns, porém, duvidavam" (Mt 28,16-17).

$\mathrm{O}$ Evangelho de Marcos narra três experiências do ressuscitado. $\mathrm{O}$ próprio texto narra e enumera as experiências: "Tendo Jesus ressuscitado na manhã do primeiro dia da semana, apareceu primeiro a Maria Madalena, da qual havia expulsado sete demônios. Foi ela que deu a notícia aos que tinham vivido com ele, mas que estavam de luto e choravam. Quando ouviram dizer que Jesus estava vivo e tinha sido visto por ela, não acreditaram. Mais tarde, Jesus apareceu de outra forma a dois discípulos que se dirigiam para o interior. Eles também voltaram e deram a notícia aos outros, mas nem mesmo neles acreditaram. Por fim, apareceu aos Onze, quando estavam à mesa. Repre- 
endeu-lhes a incredulidade e dureza de coração por não terem acreditado nos que o tinham visto ressuscitado dos mortos" (Mc 16,9-14).

No texto do Evangelho de Lucas, temos a informação de três experiências do ressuscitado, sendo que duas delas são narradas e a outra apenas informada. A primeira delas é posta dentro de um texto relativamente longo (Lc 24,1-35), o dos discípulos de Emaús. Nesta narrativa o ressuscitado caminha com dois discípulos em direção à cidade de Emaús. O evangelista dá a entender que ficaram longo tempo juntos, sem que estes o reconhecessem. Somente à noite, depois de o terem convidado a permanecer com eles, durante a refeição é que eles o reconhecem: "E aconteceu que, enquanto estava com eles à mesa, tomou o pão, rezou a benção, partiu-o e lhes deu. Então abriram-se os olhos deles e o reconheceram, mas ele desapareceu" (Lc 24,30-31). Voltaram imediatamente a Jerusalém, onde encontram os outros discípulos que lhe narram: "O Senhor ressuscitou de verdade e apareceu a Simão" (Lc $24,34)$, experiência esta que não é narrada. E logo em seguida narra-se a experiência dos Onze com o ressuscitado: "Enquanto falavam, Jesus apresentou-se no meio deles e disse: 'A paz esteja convosco'. Assustados e cheios de medo, julgavam estar vendo um espírito" (Lc 24,36-37). É Jesus mesmo que os convence de sua presença e após terem tomado uma refeição juntos, Jesus os exorta a permanecer na cidade "até que sejais revestidos da força do alto" $($ Lc 24,49) e depois disso sobe ao céu.

O Evangelho de João é o mais pródigo em narrativas de experiências do ressuscitado. A primeira delas acontece com Maria Madalena, que inicialmente não o reconhece. Só o reconhece quando ele a chama pelo nome: "Respondeu Jesus: 'Maria'. Ela virou-se e disse em hebraico: 'Rabuni', - que quer dizer Mestre. Jesus disse: 'Não me retenhas porque ainda não subi ao Pai. Vai aos meus irmãos e dize-lhes: subo para o meu Pai e o vosso Pai, meu Deus e o vosso Deus'. Maria Madalena foi anunciar aos discípulos que tinha visto o Senhor" (Jo 20,16-18). Na segunda narrativa de João, o ressuscitado aos discípulos que estavam trancados por medo dos judeus: "Jesus chegou, pôs-se no meio deles e disse: 'A paz esteja convosco'. Dito isto, mostrou-lhes as mãos e o lado. Os discípulos se alegraram por ver o Senhor" (Jo 20,19-20). Mas Tomé não estava com o grupo e quando soube da experiência do ressuscitado, não acreditou na narrativa dos outros. Mas: "Oito dias depois, os discípulos estavam outra vez no mesmo lugar, e Tomé com eles. Jesus entrou com as portas fechadas pôs-se no meio deles e disse: 'A paz esteja convosco'. Depois disse a Tome: 'Põe aqui o dedo e olha as minhas mãos, estende a mão e põe no meu lado, e não sejas incrédulo mas 
homem de fé'. Tomé respondeu-lhe: 'Meu Senhor e meus Deus"' (Jo 20,26-28). No apêndice ao Evangelho de João aparece mais uma longa cena de uma experiência com o ressuscitado, junto ao mar de Tiberíades. O ressuscitado apareceu proporcionando aos discípulos uma pesca milagrosa e por isso é reconhecido: "O discípulo a quem Jesus amava disse a Pedro: 'É o Senhor"” (Jo 21,7). Depois disto há o longo diálogo entre Simão e Jesus: "Simão, filho de João, tu me amas mais do que estes?" (Jo 21,15), pergunta que é repetida três vezes, sempre com a resposta para apascentar os cordeiros (ou as ovelhas). A cena se encerra com um diálogo entre Jesus e Pedro, no qual é incluído o discípulo a quem Jesus amava.

O texto dos Atos dos Apóstolos, em seu inicio, relata que Jesus "depois da paixão, apresentou-se vivo a eles, dando-lhes muitas provas, aparecendo durante quarenta dias e falando das coisas referentes ao reino de Deus" (At 1,3).

As narrativas mais antigas de experiências do ressuscitado são, porém de Paulo, com os textos das cartas escritas antes dos textos evangélicos. Assim Paulo (em 1Cor 15,3b-5, considerado um texto recolhido por Paulo, ou seja, já presente na comunidade primitiva quando Paulo escreve) narra: "eu vos transmiti em primeiro lugar o que eu mesmo recebi: que Cristo morreu por nossos pecados, segundo as escrituras; que foi sepultado; que ressuscitou ao terceiro dia, segundo as escrituras; que apareceu a Cefas e depois aos Doze". E continua o texto de Paulo: "Posteriormente apareceu a mais de quinhentos irmãos de uma vez, dos quais muitos ainda vivem, outros já morreram. Depois apareceu a Tiago e depois a todos os apóstolos. E por último apareceu também a mim, como a um filho abortivo" (1Cor 15,6-8).

Ora, quis colocar aqui literalmente as aparições do ressuscitado narradas no texto bíblico para mostrar a presença de diversidade. Há claramente um pluralismo muito grande que foi acolhido e deixado no testemunho textual. Todos eles contribuem para a compreensão de ressurreição. Mas nenhuma narrativa se impôs: permaneceram em igualdade de princípio e todas legítimas. O pluralismo de narrativas não é sentido pela comunidade como contraditório. Nem a comunidade primitiva sentiu a necessidade de se reconhecer apenas uma delas como a correta. Poderíamos pegar outros exemplos (como o fato de no início ter havido a compreensão plural de Igreja [= as igrejas] e não de uma única instituição) para demonstrar a capacidade da tradição cristã em seu início de acolher e deixar permanecer diversidade.

Fica assim claro que no processo de constituição da base cristã para a fé (a ressurreição: "E se Jesus não ressuscitou, vã é a nossa fé”, diz Paul), contata-se a presença de pluralismo. Mesmo que se possa dizer hoje que uma 
destas narrativas tem seu interesse, que surgiu em contexto diferente, que tem intenções diferentes, fato é que a comunidade acolheu a todas e a todas legitimou, seu a preocupação de unificação.

\section{b) Dogma como processo de síntese (da interpretação da fé)}

A ideia de que é necessária uma compreensão única e correta da fé (uma orto-doxa, ortodoxia) nasce somente mais tarde, em um processo de necessidade de síntese da interpretação da fé. Em alguns casos, mesmo se tratando de temas centrais à fé, este processo de síntese levou séculos. É o caso da compreensão correta sobre a natureza de Jesus. Jesus é de condição humana? Jesus é de condição divina? Jesus é humano e divino? Jesus é um semi-deus? Jesus é divino, mas só de aparência humana? Jesus nasce humano, mas torna-se divino a partir do batismo?

No Cristianismo pré-niceno, ou seja, até o ano de 325, havia uma pluralidade de interpretações sobre Jesus, o Cristo. Que havia diversas tensões entre as interpretações, isto havia. Mas elas conviveram lado a lado, num grande processo de interpretação e finalmente de síntese. As definições de fé feitas nos concílios de Nicéia (325) e Constantinopla (381), por exemplo, são ponto de chegada de um processo de síntese. Não seria honesto para com o dado histórico narrar que sempre estiveram lado a lado a verdade e o erro. Esta consciência da necessidade de uma interpretação que fosse por todos acolhida só vai surgir pelo fato de haver interpretações diversas. A síntese só é possível a partir de uma situação plural. Imaginar que existe desde o início uma única interpretação verdadeira e que desta se desvirtuaram interpretações, induzindo a comunidade ao erro, é inverter a ordem do desenvolvimento dogmático. Repito: quando tradição cristã - e isto poderia ser atestado em muitíssimos casos - faz a uma definição dogmática, esta é um ponto de chegada de um longo processo de discussão, de convivência de interpretações diversas, de pluralidade sem a qual não é possível chegar a uma síntese. Para a consciência de fé cristã, ou para a identidade de fé cristã, a definição dogmática é um ponto de chegada de um longo processo de discernimento. E a existência de diversidade é para este uma necessidade.

\section{c) A necessidade da heresia para o dogma}

Neste contexto, é interessante recuperar o importante papel da heresia. Por interpretação histórica, a heresia passou a ser vista como um erro - e sobre- 
tudo no contexto da ideia da salvação - como algo nocivo à fé. Os hereges colocam em perigo a sua salvação, por terem uma compreensão errônea de fé e com isto de caminho para a salvação. Esta interpretação da palavra heresia é tardia e - infelizmente - acabou sendo quase universal.

A palavra heresia significa originalmente escolha (do grego hairesis). $\mathrm{Na}$ tradição de fé, os cristãos sempre buscaram entender, interpretar o seu modo de crer. Neste processo surgiram muitas possibilidades de interpretar a fé. A palavra heresia surge neste contexto: dentre muitas possibilidade de interpretar a fé, faz-se necessário escolhas (= heresias). Dentre as diversas possibilidades, dentre os muitos modos de pensar a fé, qual é a escolha mais adequada? Desta pergunta é que nasce o uso do termo heresia e como a escolha correta é então a ortodoxia, as outras possibilidades (outras escolhas $=$ heresias) foram descartadas. Assim nasceu a identificação entre heresia e erro na fé. Mas o que se chamou de heresia foram os muitos modos de pensar a fé que desencadearam a necessidade ou o esforço de síntese.

Visto desta maneira, a heresia não é um desvio ao dogma, mas sim o seu possibilitador. Sem este processo de síntese, no qual interpretações diversas estiveram presentes (diversas possibilidades, diversas escolhas, diversas heresias), não haveria dogma.

\section{d) Fim de consensos (compreensões) e novos consensos (novas compreensões)}

A história do esforço da tradição cristã por interpretar a sua fé é muitíssimo mais ampla que a história da formação dos dogmas. Em algumas questões a comunidade cristã sentiu a necessidade de fazer uma escolha (entre as muitas possibilidades de interpretação) e definir, portanto, a ortodoxia. Mas nem todas as situações plurais, de muitas compreensões de fé na história do cristianismo levaram a declarações dogmáticas.

Em grande parte, o cristianismo permaneceu com interpretações plurais de fé que convivem e conviveram lado a lado. Ao lado de processos de diversidade de interpretar a fé, há muitos outros processos plurais no sentir e viver a fé. Toda a dinâmica da organização eclesial, dos movimentos, das espiritualidades, das formas de vida, das devoções. A história de um cristianismo ortodoxo, de uma compreensão unificada de sua fé, é apenas uma pequena parte de uma grande história plena de diversidades que conviveram, se confrontaram, chegaram a consensos (sentimentos em comum), mas também de consensos que foram desfeitos (fim de consensos) e de outros que os substituíram. Estes 
processos plurais, e que formam sem dúvida a grande tradição cristã, viveram e vivem em dinâmicas contínuas de formação de consensos (seja locais, regionais ou para o todo), fim se consensos e formação de novos consensos.

Um exemplo histórico interessante desta dinâmica é a história do purgatório na tradição cristã. Nasce de um questionamento (impregnado de elementos culturais) sobre a situação dos fiéis entre a morte e o juízo final (status intermedius). Há a possibilidade de continuar após a morte o processo de ser acolhido por Deus? A maioria dos fieis pensa ou sente que sim quando o papa Bento XII escreve então a constituição Benedictus Deus em 1336. Não é este escrito que cria o purgatório. Ele acolhe um longo processo no qual muitas ideias estiveram presentes e, naquele escrito, pareceu ao papa haver consenso em torno de uma compreensão. Ao mesmo tempo é preciso ser realista que o consenso sobre o purgatório definido em 1336 não mais existe. Ou seja, chegou-se já há muito tempo ao fim de um consenso. E num processo de elaboração de novos consensos sobre esta pergunta, muitas continuam sendo as interpretações que irão conviver lado a lado, numa situação de pluralismo de compreensão. O que poderá levar a um outro consenso. Mas não necessariamente. Poderíamos citar uma infinidade de exemplos para mostrar como este processo dinâmico de busca de interpretação da fé é formado basicamente pela convivência da pluralidade e não pela definição de uma compreensão única (a ortodoxia).

\section{e) Dialética heresia-dogma como estrutura da fé cristã na história}

Este processo que poderíamos chamar de "dialética heresia-dogma" pode ser visto não como uma exceção na tradição cristã, mas justamente como estrutura da fé cristã na história. A tradição da compreensão cristã de fé seria pois entendida não como algo dado, mas algo que vai se constituindo sempre novamente ao longo da história. Nesta compreensão, há o pressuposto de que a situação plural é a regra e não o desvio dela.

\section{f) Fé cristã e encarnação: necessidade de tornar-se sempre novamente história}

A base teológica deste pensamento para a fé cristã encontramos na própria ideia da encarnação: a fé que necessita sempre novamente tornar-se história. A compreensão teológica da encarnação é algo que perpassa todo o modo de pensar cristão. A encarnação não pode ser entendida como fato fechado, 
como uma espécie de notícia do passado, fechado noutro tempo histórico. A encarnação é, na compreensão cristã, parte estrutural do processo de manifestação de Deus. Deus, na compreensão cristã, mostra-se, torna-se realidade na realidade humana (na carne humana). Com isto, entende a tradição cristã ser a condição humana capaz de perceber o divino e ser por ele acolhida: não em ela poder ir até Deus, mas em Deus poder entrar em sua condição e ali encontrar (e redimir) o humano. Este é o sentido mais amplo da encarnação.

Quando falamos aqui na necessidade de uma compreensão da encarnação não fechada em um ato histórico, não estamos pensando no sentido de que será necessário outra encarnação, mas no fato de por um lado a partir da encarnação a história (do ponto de vista cristão) não ser mais estranha à divindade (Deus esteve na história) e por outro da condição histórica do crente, que é de onde este encontra a revelação (em sua situação encarnada).

Com esta importância da encarnação como estrutura histórica da condição de fé e a constatação feita acima de que a história de fé cristã é sempre uma história plural, de convivência com a diversidade, de um pluralismo já presente, podemos ir adiante em nossa tentativa de mostrar a fé cristão de condição plural como um elemento importante da sua catolicidade.

\section{Fé cristã de condição plural e a catolicidade}

À fé cristã, a condição plural não lhe é alheia. Pelo contrário: é talvez o seu habitat mais comum na história. Momentos de síntese foram pontos de chegada de longos processos históricos de discernimento. Mas isto forma apenas uma parte da história da compreensão cristã de fé. Em boa parte de sua história, a pluralidade conviveu e convive em processos plurais onde se encontra aqui e acolá algum consenso (sentimento em comum), que pode chegar ao fim e levar a outros consensos (mas não necessariamente). A esta compreensão, gostaria de ligar o fato de entende-se a fé cristã, desde já os tempos primitivos, ser de condição católica.

\section{a) Pluralidade como requisito à catolicidade}

A tradição católica da fé cristã (aqui não entendido somente no sentido da tradição da Igreja Católica Apostólica Romana) se constitui justamente na sua característica de catolicidade: capacidade de ser de todo abrangente. A palavra grega katholikós é oriunda de dois termos: katá, que significa para e hólon, que 
significa o todo, de tal forma que katholikós significa literalmente para o todo. Numa tradução mais livre, catolicidade pode ser entendida como a capacidade de acolher ou abranger o todo. Pluralidade torna-se então não uma contraposição, mas um requisito para a catolicidade. Se falamos pois de uma tradição católica dentro do cristianismo, estamos falando da presença de uma capacidade de acolher a diversidade, o pluralismo ser ver nisto uma contradição, mas sim o que lhe é constitutivo, parte de seu modo de ser no mundo.

\section{b) O pluralismo como uma constante na tradição cristã de fé}

Estamos inventando a roda? Talvez, mas como dizia lá no início, o pluralismo pode ser pensando tanto na linha de uma forma de viver, como numa forma de ver e interpretar o mundo. E talvez hoje estejamos vendo coisas que antes não eram assim vistas. Talvez o fato de estarmos vivendo em uma cultura plural nos tenha dado mais capacidade de perceber que a catolicidade desta tradição de fé. Neste sentido, podemos ver muitos sinais de catolicidade deixados na tradição, como formas de pluralismo.

Já apontei aqui detalhadamente para o pluralismo acolhido da tradição cristã no que tange à narrativa da experiência fundante do cristianismo: a experiência do ressuscitado. Dou outros dois exemplos, sem aprofundar-me na questão: o primeiro deles é o fato de ter a tradição acolhido em sua lista oficial de textos quatro evangelhos (entre outros textos de evangelhos que circulavam na época). Entre os quatro textos há informações que divergem entre si sobre diversos assuntos, mas mesmo assim a tradição acolheu e deixou lado a lado esta diversidade.

Outro exemplo interessante é o nascimento da instituição Igreja. Os textos das cartas de Paulo conservam a informação muito clara que a Igreja nasceu plural. Não há uma igreja inicialmente: há igrejas diversas, que - sobretudo pela atividade de Paulo - se espalham da Ásia Menor para dentro do mundo grego e do império romano. A consciência de que há uma única Igreja - cuja cabeça é Cristo - mostra já que houve um processo de síntese, do qual chegou-se a este sentimento em comum (consenso).

Destes dois exemplos de pluralismo acolhido e perenes na história da compreensão cristã da fé, poderíamos partir para uma infinidade de outros ao longo da história. Mas este não é o nosso intuito aqui. O que queremos apontar é que a situação de pluralismo cultural que vivemos hoje não é algo que necessariamente cause embaraço à fé cristã. Pelo contrário, ela traz consigo a chance de evidenciarmos a catolicidade cristã. 


\section{Fé plural como chance da catolicidade}

A situação de pluralismo cultural que vivemos hoje poderia ser então visto positivamente como uma chance da catolicidade. Diferente da catolicidade de outras épocas, mas sem deixar de ser catolicidade: característica de ter uma capacidade abrangente, universal, não restrita, fechada ou provinciana.

Claro que se poderia falar do desafio de manter a catolicidade: prefiro dizer que antes de ser um desafio, a situação de pluralismo cultural hoje vivida pode significar uma chance à catolicidade do cristianismo. Onde se mostraria a catolicidade neste contexto de pluralismo cultural hoje? Vamos tentar mostrar isto com alguns exemplos.

\section{a) Fé cristã como opção, uma opção feita}

Falávamos anteriormente que uma das características do pluralismo cultural é a necessidade da escolha. Tudo não apenas pode ser escolhido, mas escolher e uma necessidade. Muitas são as opções em todos os níveis e cabe ao indivíduo a tarefa da escolha. E através da escolha ele coloca um ranking de valor: tem valor o que foi escolhido.

Dentro do pluralismo cultural, a religião, a fé ou a espiritualidade é uma opção. Poder pensar a fé cristã como opção não no sentido de algo de somenos importância, mas algo a ser escolhido. As outras possibilidades permanecem, mas esta é a opção (positiva) assumida pelo crente: sou cristão porque positivamente optei, escolhi esta forma de vida. Opção que só é verdadeira então quando se mantém como escolhida: não é verdadeira em si. E esta opção feita, mantém-se como sinal da catolicidade, à medida que permanece aberta a outros esta mesma opção cristã, mas interpretada, sentida e vivida de forma diversa.

Pensar a fé cristã como opção de escolha - mas uma opção feita - não seria desprestigiá-lo como tradição de fé. Pelo contrário, traz a chance de se entender o cristianismo como algo a ser escolhido positiva como forma de vida, algo que - ao ser escolhido - torna-se verdade no sentido existencial para aqueles que fazem esta opção. Antes de enfraquecer, pensar o cristianismo como opção existencial, de forma de existir, é colocá-lo como possibilidade concreta de ser na vida do fiel, caminho, verdade e vida. Não como afirmação de princípio, mas como ponto de chegada de um processo de síntese (pessoal ou grupal). Assim pensado, torna-se ele realidade vivida muito mais que verdade anunciada. 
É provável que o cristianismo nascido como "opção optada" seja ou vá ser diferente do cristianismo de tradição cultural. Mas esta é - do ponto de vista teológico - mais uma consequência do efeito encarnação.

\section{b) Religião cristã como oferta, uma oferta}

No contexto de pluralismo cultural, religião é uma oferta. Muitas são as ofertas de sentido religioso que concorrem lado a lado, em condição de igualdade e situação de legitimidade. Neste contexto, o cristianismo é visto como mais uma oferta de sentido religioso, ao lado de outras. Mais que isto, dado à pluralidade existente dentro do próprio cristianismo, ele se vê ofertado de forma bastante fragmentada e múltipla. A oferta cristã concorre não apenas ofertas religiosas outras, concorre também entre pares, com ofertas diferenciadas de cristianismo.

Pensar a religião cristã como oferta (algo que precisa ou pode ser oferecido) toca num ponto central do pluralismo cultural, que é a questão da identidade. Pensar o cristianismo neste contexto como uma oferta, algo que precisa mostrar sua identidade, traz novamente a chance da catolicidade: das constituições de sínteses, de compreensões diversas que estão sendo ofertadas. Como cada grupo religioso que coloca a sua possibilidade em oferta entre os outros precisa ter a clareza daquilo que está ofertando (refletir sobre a identidade, o modelo que se está apresentando), o cristianismo (ou os cristianismos) que ali se apresenta em oferta se vê obrigado a pensar naquilo que está ofertando. Nesta situação há a chance de se refletir sobre que coisas podem ser tidas como genuinamente cristãs. Ou seja, aqui se apresenta a possibilidade de se debruçar sobre as questões constitutivas do ser cristão. E como diversas são as ofertas cristãs, fica logo claro que não há consenso sobre isto, mas sim pluralismo.

O pluralismo cultural que coloca o cristianismo (os cristianismos) como uma oferta (mas que o cristão precisa oferecer ou mostrar = ter uma identidade!) é mais uma chance de catolicidade: de mostrar-se de vocação universal, capaz de abranger mais possibilidades.

\section{c) A chance da periferia: o pluralismo}

O processo histórico de sínteses (consensos) que a tradição cristã elabora é também plural no sentido de ser um diálogo entre o centro da fé (as compreensões já consolidadas e quiçá definidas como ortodoxia) e a periferia da fé (as compreensões emergentes, múltiplas que convivem lado a lado). 
Centro e periferia da fé podem ser interpretados numa compreensão de poder, de tensão entre topo e base da hierarquia, de tensão entre poder magisterial e comunidade de crentes. Mas não necessariamente: o que quero acentuar é que pela situação de pluralismo, compreensões que estavam e/ou estão à margem, na periferia, circulam na comunidade dos fieis. Esta situação sempre ocorreu. A periferia da fé sempre foi mais plural que o centro.

O novo na condição de pluralismo cultural talvez seja a legitimidade e igualdade que compreensões da fé, que não sejam já tradicionalmente consolidadas, circulam nesta condição pluralista com maior condição de igualdade e legitimidade, aparecendo por um lado como uma opção optável e por outro lado aumentando a dinamicidade dos processos de sínteses, de formação de consensos, de fim dos mesmos e de formação de novos consensos. Este processo, que definimos antes como constante na tradição de fé cristã, vem à tona numa situação de pluralismo cultural com muito mais evidência e pode ser acolhido com mais facilidade, sendo mais um elemento de recuperação da catolicidade do cristianismo.

A própria teologia, nesta nova situação de pluralismo cultural, apresenta mais possibilidades de dinamismo de tal forma que teologias periféricas, no sentido de não serem as teologias dos lugares consolidados, ganham maior visibilidade e legitimidade. É o longo processo das teologias feitas a partir de lugares periféricos apresentando-se como formas legítimas de refletir sobre a tradição cristã. Esta teologia feita em lugares distintos se constitui também a partir de novos métodos, o que dá a toda a teologia a chance da catolicidade, de abranger nela com pé de igualdade estas formas de pensar. É o que Ana Maria Tepedino chama de "fragilidade" como um novo lugar da teologia ${ }^{4}$.

\section{d) Pluralismo como chance para novos consensos deste tempo histórico: a participação na encarnação}

Em cada tempo histórico os cristãos não podem se furtar de assumir a sua identidade de fé: isto é a condição histórica, de viver a fé num tempo e num espaço histórico concretos. Mas para o cristianismo, o "efeito encarnação" faz com que isto se revista de uma importância teológica, pois Deus se fez história e somente nela é ele - na compreensão cristã - encontrável. É o que Andrés Torres Queiruga chama de "a 'particularidade' como necessidade histórica"5.

\footnotetext{
${ }^{4}$ Cf. TEPEDINO, A. M., "Passagem do lugar do 'poder' ao lugar da 'fragilidade'. Reflexões sobre o método teológico em tempos de pós-modernidade”. REB 281 (2011), p. 200-208.

5 QUEIRUGA, A. T. Autocompreensão cristã. Diálogo das religiões. São Paulo: Paulinas, 2007, p. 39.
} 
Se o pluralismo em que vivemos representa por um lado fragmentação, multiplicidade, diversidade, ele pode, por outro, ser chance de se constituir consensos deste e neste tempo histórico. E com isto, ser parte do processo encarnatório da compreensão cristã.

\section{A título de conclusão}

Tudo isto não é líquido demais? Talvez, mas como afirma o Gênesis: "No princípio... um vento impetuoso soprava sobre as águas" (Gn 1,2) e não sobre a terra firme.

\section{Referências bibliográficas}

BAKAS, A., Além da Crise - O futuro do capitalismo. Rio de Janeiro: Qualitymark, 2010.

BAUMAN, Z., O Mal-Estar da Pós-Modernidade. Rio de Janeiro: Zahar, 1998.

QUEIRUGA, A. T., Autocompreensão cristã. Diálogo das religiões. São Paulo: Paulinas, 2007.

RIBEIRO, C. de O., "Ecumenismo, pluralismo e religiões. A busca de novos referenciais". REB 287 (2012) p. 651-663.

TEPEDINO, A. M., 'Passagem do lugar do 'poder' ao lugar da 'fragilidade'. Reflexões sobre o método teológico em tempos de pós-modernidade". REB 281 (2011) p. 200-208.

\section{Volney J. Berkenbrock}

Doutor em Teologia pela Friedrich-Wilhelm-Universität de Bonn, Alemanha Professor do Departamento de Ciência da Religião e do Programa de Pós-Graduação em Ciência da Religião da Universidade Federal de Juiz de Fora, MG

Juiz de Fora/MG - Brasil E-mail: volney@itf.org.br

Recebido em: $17 / 11 / 13$

Aprovado em: 18/12/13 